\title{
Nutritive Value of Commercially Important Fish Species from Selected Lakes in Ethiopia
}

\author{
Bezuayehu Gutema Asefa ${ }^{*}$, Fikadu Hailemichael Tsige \\ Food Science and Nutrition Research, National Fishery and Aquatic Life Research Center, Ethiopian Institute of Agricultural Research, \\ Sebeta, Ethiopia
}

Email address:

bezuayehug7@gmail.com (B. G. Asefa)

${ }^{*}$ Corresponding author

\section{To cite this article:}

Bezuayehu Gutema Asefa, Fikadu Hailemichael Tsige. Nutritive Value of Commercially Important Fish Species from Selected Lakes in Ethiopia. Science Research. Vol. 9, No. 3, 2021, pp. 41-45. doi: 10.11648/j.sr.20210903.12

Received: April 17, 2021; Accepted: June 9, 2021; Published: June 16, 2021

\begin{abstract}
Knowledge on nutrient content of important foods is a vital tool in understanding the associations between production, access, and nutrient intakes. Fish is one of such foods considered important for food and nutrition security in Ethiopia's national nutrition strategy. However, limited studies are conducted on nutritional profiles of fish species found in the country. This study was conducted to generate information on the nutritional profile of commercially important fish species. Proximate composition and some mineral content of six fish species obtained from four lakes (Tana, Ziway, Chamo, and Abaya) were analyzed. The moisture content varied between 78.05 to $81.18 \mathrm{mg} / 100 \mathrm{~g}$. The protein content was in the range between 15.87 to $18.92 \mathrm{mg} / 100 \mathrm{~g}$. The fat content varied from 0.87 to $3.48 \mathrm{mg} / 100 \mathrm{~g}$. the ash and carbohydrate contents varied significantly between the different species in all the lakes. Calcium content ranged from 52.34 to $250.43 \mathrm{mg} / 100 \mathrm{~g}$. The phosphorous content was in a range from 490 to $960 \mathrm{mg} / 100 \mathrm{~g}$. The range of sodium content was between 41.37 to 164.28 $\mathrm{mg} / 100 \mathrm{~g}$, while the range of potassium content was 389.75 to $1887.44 \mathrm{mg} / 100 \mathrm{~g}$. The finding indicated the nutritional significance of commercially important fish in Ethiopia. Besides, C. gariepinus species from all water bodies have shown high energy content compared to other species, indicating the necessity to consider this species as a primary candidate species in nutrition-sensitive aquaculture. Further study is necessary to profile other fish species, and to include all indicator parameters of fish nutritional value.
\end{abstract}

Keywords: Fish Species, Nutrition, Proximate Analysis, Ethiopia, Nutrition-sensitive

\section{Introduction}

Fish and fish products, as they are a valuable source of nutrients and micronutrients of vital importance for diversified and healthy foods, play a critical role in nutrition and global food security $[1,2]$. The importance of fish as a food group is greater in lower-income countries due to its compositions such as vitamins and minerals needed to address some of the most serious and prevalent nutritional deficiencies. Particularly for pregnant women and very young children, the role of fish as a component in a healthy diet is enhanced since it contributes to neurodevelopment during the most critical stages of the growth of an unborn or young child. Fish may provide a much-needed means of nutritional diversification that is relatively cheap and locally available in low-income communities that rely heavily on a limited range of calorie-dense staple foods. Although the yearly average consumption of fish per person may be low, even small amounts of fish may offer essential amino acids, fats, and micronutrients, such as iron, iodine, vitamin D, and calcium, which are often deficient in staple diets of the poor [1].

In Ethiopia, a moderately exploited fishery sector exists with a high diversity of close to 180 freshwater fish species [2]. Fishing is carried out in almost all water bodies in Ethiopia. However, most of the catch is contributed from Chamo, Ziway, Tana, and Abaya lakes [4]. Although the country has an estimated fish production capacity of 94,500 tonnes/year [4], the fish consumption per person is low at a mere $0.5 \mathrm{Kg}$ per year, while 12 to $17 \mathrm{Kg}$ of fish per capita per year is recommended.

Malnutrition, largely caused by inadequate micronutrient 
intake, remains prevalent in Ethiopia with 37\% stunted, $7 \%$ wasted and $21 \%$ underweight children below the age of five; and $23 \%$ women of the reproductive age (15-49 years) reside [5]. Even though the current contribution of the fishery sector to the food and nutrition security is low, it has been recognized as an important resource in the country's national nutrition strategies [6].

Information on the nutrient content of important foods is a vital tool in understanding the associations between production, access, and nutrient intakes. Besides, the knowledge can be used to devise policies and programs such as the development of improved production systems [7], to ensure that food supply optimally satisfies population nutrient demands [8]. Despite the potential importance of fish in a diet, only some fragmented studies were performed on the nutrient composition profiling of Ethiopian fish species [9-15]. The objective of this study was to assess proximate composition and mineral profiles of commercially important fish species from four major fish producing lakes in Ethiopia.

\section{Materials and Methods}

\subsection{Fish Collection}

A detailed description of each sample including local name, scientific name, and the number of each composite sample is given in Table 1. A total of 84 fish were collected from the landing sites in three rift valley lakes: Ziway, Chamo, and Abaya, and one highland lake, Tana. A varying number of fish were collected depending on the size (total length) of each fish. For those fish with a total length $(T L)$ less than $40 \mathrm{~cm}$, nine individual fish were taken as one composite sample. On the other hand, six individual fish were combined into one sample for those with a $T L$ greater than $40 \mathrm{~cm}$. After grouping, the edible portion of each fish was packed into a polyethylene plastic bag and transported to the National Fishery and Aquatic Life Research Center (NFALRC) in an insulated icebox within twelve hours.

Table 1. Sample description.

\begin{tabular}{lllll}
\hline Lake & Species name & $\begin{array}{l}\text { Local } \\
\text { name }\end{array}$ & $\begin{array}{l}\text { Total length } \\
\text { (cm)/average }\end{array}$ & $\begin{array}{l}\text { Number } \\
\text { of fish }\end{array}$ \\
\hline \multirow{3}{*}{ Tana } & Tilapia & Koroso & $17-40 / 28.5$ & 9 \\
& Barbus & Barbe & $29-53 / 41$ & 6 \\
& Catfish & Ambaza & $34-72 / 53$ & 6 \\
& Tilapia & Koroso & $22-33 / 27.5$ & 9 \\
\multirow{5}{*}{ Ziway } & Catfish & Ambaza & $39-51 / 45$ & 6 \\
& Common carp & Dabe & $31-45 / 38$ & 9 \\
& Crucian carp & Bilcha & $26-35 / 30.5$ & 9 \\
\multirow{5}{*}{ Chamo } & Tilapia & Koroso & $34-38 / 36$ & 9 \\
\multirow{4}{*}{ Abaya } & Nile perch & Nech asa & $40.7-57.5 / 49.1$ & 6 \\
& Tilapia & Koroso & $18-26 / 22$ & 9 \\
& Nile perch & Nech asa & $52-60 / 56$ & 6 \\
\hline
\end{tabular}

\subsection{Determination of Nutritional Value}

\subsubsection{Determination of Protein Content}

Crude protein was determined by the Kjeldahl method according to AOAC procedure [16]. One gram of sample was weighed and added to the digestion flask. In the digestion flask, $12 \mathrm{ml}$ of concentrated $\mathrm{H}_{2} \mathrm{SO}_{4}$ and $1 \mathrm{~g}$ of catalyst was added. It was digested at $400^{\circ} \mathrm{C}$ for $2^{1 / 2}$ hours. After digestion was completed, the content in the flask was diluted by $50 \mathrm{ml}$ of water and neutralized using $40 \%$ of $40 \mathrm{ml} \mathrm{NaOH}$. Upon addition of $\mathrm{NaOH}$, the ammonium was distilled off using steam distillation apparatus and trapped into a $2 \%$ boric acid and solution containing methyl blue and methyl red indicators. Finally, titration of the ammonium attached to borate anion was titrated with standardized $0.1 \mathrm{~N} \mathrm{HCl}$, and the amount of $\mathrm{HCl}$. consumed was recorded and total crude protein was calculated as total nitrogen.

$$
\begin{gathered}
\% N=\frac{(\text { ml titrated-blank }) \times N \times \text { Eq.wt of Nitrogen }}{1000 \times \mathrm{Wt}} \times 100 \\
\% \text { Crude Protein }=\% N \times 6.25
\end{gathered}
$$

Where; $\mathrm{Wt}=$ weight of the sample, $\mathrm{N}=$ concentration of sulfuric acid

\subsubsection{Determination of Moisture Content}

The sample moisture content was analyzed following AOAC procedure [17]. A drying dish was dried in an oven at $105^{\circ} \mathrm{C}$ for 1 hour and placed in a desiccator to cool. The weight of the drying dish $\left(\mathrm{W}_{1}\right)$ was recorded. Five grams of sample was weighed in the dry dish $\left(\mathrm{W}_{2}\right)$ and oven-dried at $105^{\circ} \mathrm{C}$ for 3 hours. After cooling in a desiccator to room temperature, it was again weighed $\left(\mathrm{W}_{3}\right)$ and brought to constant weight by putting it again in an oven for an extra one hour.

$$
\text { Moisture (\%) }=\frac{W 2-W 3}{W 2-W 1} \times 100
$$

\subsubsection{Determination of Fat Content}

Total lipid was extracted by a diethyl ether solvent system [18]. A five gram of the sample was weighed and extracted into a $250 \mathrm{ml}$ round-bottom flask with $50 \mathrm{ml}$ diethyl ether for about 4 hours at $110^{\circ} \mathrm{C}$ in the Soxhlet extractor. Then, the organic solvent was removed at $40-60^{\circ} \mathrm{C}$ under reduced pressure using a rotary evaporator. Finally, the weight of fat was calculated using the following formulae.

$$
\begin{aligned}
\text { Weight of fat }= & (\text { weight of container }+ \text { extracted fat })- \\
& \text { (weight of container })
\end{aligned}
$$

and

$$
\text { Fat content }(\%)=\frac{\text { Mass of fat extracted }(g)}{\text { Weight of original sample }(g)} \times 100
$$

\subsubsection{Determination of Ash Content}

Clean crucibles were placed under a muffle furnace at $550^{\circ} \mathrm{C}$ for one hour. Crucibles were moved from the furnace to desiccators and cooled to room temperature. These crucibles were weighed quickly to prevent moisture absorption, and $5 \mathrm{~g}$ of the sample was added. The crucibles, containing the sample were placed in a muffle furnace and heated at $550^{\circ} \mathrm{C}$ overnight. Then, crucibles were taken to desiccators and cooled to room temperature. After cooling, crucibles were weighed quickly to prevent moisture absorption [17]. 


$$
\text { Ash }(\%)=\frac{\text { Wt.of ash }}{\text { Wt of sample }} \times 100
$$

\subsubsection{Determination of Mineral Content}

The mineral content determination was carried out following AOAC procedure [19]. About 5 grams of homogenized fillet sample was digested in a concentrated $\mathrm{HNO}_{3}$ and quantitatively transferred to a $50 \mathrm{ml}$ volumetric flask. Then the volume was adjusted using a distilled water. A blank digest was prepared in the same way. After preparation of the digest, $\mathrm{Na}, \mathrm{K}, \mathrm{Ca}$, and $\mathrm{P}$ were determined using flame photometer.

\subsection{Statistical Analysis}

Statistical analysis was done using J.M.P. Pro version 13 software. One-way analysis of variance (ANOVA) was used to compare the mean composition between species in each lake. The level of statistical significance was considered at $p<0.05$.

\section{Results and Discussion}

\subsection{Proximate Composition}

The proximate composition of muscle tissues of six fish species collected from four freshwater lakes in Ethiopia is shown in (Table 2). Results of some mineral analysis are presented in (Table 3). Constituent data were compared between different species of each lake using a one-way analysis of variance.

Table 2. Proximate composition

\begin{tabular}{|c|c|c|c|c|c|c|c|}
\hline \multirow{2}{*}{ Lake } & \multirow{2}{*}{ Species } & \multicolumn{6}{|c|}{ Nutrient content per $100 \mathrm{~g}$ raw edible portion } \\
\hline & & Moisture (g) & Protein (g) & Fat (g) & Ash (g) & Carbohydrate (g) & Energy (kcal) \\
\hline \multirow{3}{*}{ Tana } & O. niloticus & $78.43 \pm 1.25$ & $18.32 \pm 1.68$ & $1.62 \pm 0.17$ & $1.15 \pm 0.01^{\mathrm{a}}$ & $0.48 \pm 0.29$ & $97.18 \pm 7.72^{b}$ \\
\hline & L. intermidious & $78.76 \pm 0.36$ & $17.31 \pm 0.30$ & $2.25 \pm 0.24$ & $1.12 \pm 0.03^{\mathrm{a}}$ & $0.56 \pm 0.44$ & $115.04 \pm 2.08^{\mathrm{ab}}$ \\
\hline & C. gariepinus & $79.42 \pm 0.15$ & $15.97 \pm 0.18$ & $2.60 \pm 0.99$ & $1.05 \pm 0.02^{\mathrm{b}}$ & $0.96 \pm 0.64$ & $125.08 \pm 12.56^{\mathrm{a}}$ \\
\hline \multirow{4}{*}{ Ziway } & C. carp & $81.18 \pm 0.77$ & $16.21 \pm 0.65$ & $1.29 \pm 1.10$ & $0.79 \pm 0.02^{\mathrm{b}}$ & $0.54 \pm 0.25$ & $76.42 \pm 12.37$ \\
\hline & C. carpio & $80.34 \pm 0.47$ & $16.45 \pm 0.73$ & $2.12 \pm 0.29$ & $0.71 \pm 0.01^{\mathrm{b}}$ & $0.38 \pm 0.32$ & $93.88 \pm 4.11$ \\
\hline & C. gariepinus & $79.45 \pm 0.83$ & $15.87 \pm 0.98$ & $3.48 \pm 1.56$ & $0.77 \pm 0.03^{\mathrm{b}}$ & $0.44 \pm 0.05$ & $109.83 \pm 25.55$ \\
\hline & O. niloticus & $78.87 \pm 1.39$ & $16.92 \pm 0.60$ & $1.51 \pm 0.70$ & $1.07 \pm 0.05^{\mathrm{a}}$ & $1.63 \pm 1.32$ & $94.64 \pm 7.99$ \\
\hline \multirow{2}{*}{ Chamo } & L. niloticus & $78.12 \pm 1.27$ & $17.06 \pm 0.34$ & $2.13 \pm 0.36$ & $1.13 \pm 0.01$ & $1.56 \pm 1.14$ & $87.41 \pm 4.57$ \\
\hline & O. niloticus & $78.05 \pm 1.03$ & $18.92 \pm 0.62$ & $1.53 \pm 0.35$ & $1.04 \pm 0.03$ & $0.31 \pm 0.18$ & $89.42 \pm 0.82$ \\
\hline \multirow{2}{*}{ Abaya } & L. niloticus & $78.34 \pm 0.36$ & $18.17 \pm 0.38$ & $0.86 \pm 0.87$ & $1.17 \pm 0.01^{*}$ & $1.46 \pm 0.55^{*}$ & $80.42 \pm 3.03$ \\
\hline & O. niloticus & $78.74 \pm 0.78$ & $18.43 \pm 0.38$ & $1.42 \pm 0.39$ & $1.08 \pm 0.05^{*}$ & $0.33 \pm 0.12^{*}$ & $86.47 \pm 3.03$ \\
\hline
\end{tabular}

The result showed a significant variation $(p<0.05)$ in ash and carbohydrate content between the fish species from all Lakes. The water content varied between $78.05 \pm 1.03 \%$ in O. niloticus species of the Lake Chamo to $81.18 \pm 0.77 \%$ in C. carp species of Lake Ziway. Protein content was in the range between $15.87 \pm 0.98 \%$ in $C$. gariepinus species of the Lake Ziway to $18.92 \pm 0.62 \%$ in $O$. niloticus species from lake Chamo. The least fat content was $0.86 \pm 0.87 \%$, which was recorded from L. niloticus species of Lake Abaya, while the highest fat content was $3.48 \pm 1.56$ which was recorded from C. gariepinus species of Lake Ziway. Ash content of the fish species from all lakes except Chamo showed statistically significant variation. The range in ash content falls between $0.71 \pm 0.01$ in C. carpio species from lake Ziway to $1.17 \pm$ 0.01 in L. niloticus species from lake Abaya. The calculated carbohydrate content ranged between $0.31 \pm 0.18$ to $1.63 \pm$ 1.32 in $O$. niloticus species from lake Chamo and Ziway respectively.

The finding showed that most of the proximate composition parameters didn't show significant variation depending on species. However, due to high-fat content in $C$. gariepinus species, the energy value of this species exceeds other species under the study. This means, in alleviating energy deficiency, which is one of the prevailing forms of malnutrition in the country, C. gariepinus can contribute better than other species. The fact that $C$. gariepinus has better energy content may have to shift the insight of aquaculture strategies to be nutrition-sensitive, and should prioritize catfish as a candidate species in aquaculture. Besides the higher energy content, farming $C$. gariepinus in aquaculture has several advantages, one of which its ability to grow in poor water quality with little effort of pond management.

\subsection{Mineral Composition}

The phosphorous, calcium, sodium, and potassium composition of the six fish species from five Ethiopian lakes are presented in mg per $100 \mathrm{~g}$ unit in (Table 3). Calcium content ranged from 52.34 to $250.43 \mathrm{mg} / 100 \mathrm{~g}$, which is consistent with previous findings [20]. The phosphorous content in species analyzed under the study was from 490 to $960 \mathrm{mg} / 100 \mathrm{~g}$ of the fillet. The range was in agreement with earlier report [20], and a narrower range was found compared to Bogard et al., [8], who obtained a phosphorous content 110 to $1000 \mathrm{mg} / 100 \mathrm{~g}$. The range of sodium content (41.37 to $164.28 \mathrm{mg} / 100 \mathrm{~g}$ ) was comparable with other studies on various fish species $[8,20]$. The range of potassium content ( 389.75 to $1887.44 \mathrm{mg} / 100 \mathrm{~g}$ ) was varied from previously reported findings in different fish species $[8,20]$. 
Table 3. Mineral content of six fish species from four lakes in Ethiopia.

\begin{tabular}{lllll}
\hline Source & Species & Ca $(\mathbf{m g} / \mathbf{1 0 0 g})$ & P $(\mathbf{m g} / \mathbf{1 0 0 g})$ & Na $(\mathbf{m g} / \mathbf{1 0 0 g})$ \\
\hline \multirow{3}{*}{ Tana } & O. niloticus & $66.42 \pm 18.68$ & $820 \pm 40$ & $61.37 \pm 3.35$ \\
& L. intermedious & $110.85 \pm 0.28$ & $770 \pm 20$ & $62.63 \pm 8.80$ \\
& C. gariepinus & $75.52 \pm 14.95$ & $710 \pm 10$ & $164.28 \pm 16.64$ \\
& O. niloticus & $85.35 \pm 4.95$ & $720 \pm 40$ & $41.37 \pm 5.02$ \\
Ziway & C. gariepinus & $192.24 \pm 6.73$ & $490 \pm 10$ & $47.45 \pm 4.25$ \\
& C. carpio & $172.97 \pm 52.97$ & $570 \pm 30$ & $60.45 \pm 10.74$ \\
& C. carp & $250.43 \pm 7.43$ & $700 \pm 20$ & $53.66 \pm 2.41$ \\
Chamo & O. niloticus & $52.34 \pm 20.31$ & $870 \pm 30$ & $70.34 \pm 7.36$ \\
& L. niloticus & $166.95 \pm 11.54$ & $500 \pm 20$ & $71.05 \pm 3.96$ \\
Abaya & O. niloticus & $136.97 \pm 8.68$ & $960 \pm 30$ & $118.35 \pm 8.44$ \\
RDA & L. niloticus & $94.73 \pm 1.75$ & $850 \pm 40$ & $71.05 \pm 1.22$ \\
\hline
\end{tabular}

\section{Conclusion}

The data presented in this research indicated the nutritional significance of commercially important fish species in four Ethiopian lakes. Proximate composition and some mineral content were evaluated. The finding indicated the potential of commercially important fish species in contributing to the daily nutrient requirement. Besides, the importance of nutrition-sensitive prioritization of candidate fish species for aquaculture should be taken into account. Based on the total energy content, catfish surpasses other species under this study, and thus a priority should be given in selecting candidate species for aquaculture farms.

\section{Recommendations}

A comprehensive study is recommended to address species other than those with commercial importance and to include all indicator parameters of nutritional value. Despite the limitations, this paper expands the current knowledge on the proximate composition and mineral content of commercially important fish species in Ethiopia since it incorporates the four major fish-producing lakes in the country. It would be important to determine all the micronutrients that have public health significance.

\section{Acknowledgements}

The authors are grateful to thank the Ethiopian Institute of Agricultural Research for funding this work.

\section{References}

[1] FAO. The State of World Fisheries and Aquaculture 2018: Meeting the sustainable development goals. Rome. Licence: CC BY-NC-SA 3.0 IGO, 2018.

[2] Sarvenaz Khalili Tilami \& Sabine Sampels (2017): Nutritional Value of Fish: Lipids, Proteins, Vitamins, and Minerals, Reviews in Fisheries Science \& Aquaculture, DOI: 10.1080/23308249.2017.1399104
[3] Golubtsov AS, Mina MV. Fish species diversity in the main drainage systems of Ethiopia: Current state of knowledge and research perspectives. Ethiopian Journal of Natural Resources. $2003 ; 5$ (2): 281-318.

[4] Tesfaye G Wolff M. The state of inland fisheries in Ethiopia: A synopsis with updated estimates of potential yield. In: Ecohydrology and Hydrobiology. 2014; 14 (3): 200-219. Elsevier. https://doi.org/10.1016/j.ecohyd.2014.05.001

[5] Ethiopian Public Health Institute (EPHI), ICF. Ethiopia Mini Demographic and Health Survey 2019: Key Indicators, Rockville, Maryland, USA, 2019.

[6] Government of the Federal Democratic Republic of Ethiopia. National Nutrition Programme: June 2013-June 2015. 2015.

[7] Thilsted SH, Wahab MA. Pond polyculture technologies combat micronutrient deficiencies and increase household income in Bangladesh. CGIAR Research Program on Aquatic Agricultural Systems. Penang, Malaysia. Policy Brief. 2014; AAS-2014-09.

[8] Bogard JR, Thilsted SH, Marks GC, Wahab A, Hossain MAR, Jakobsen J, Stangoulis J. Nutrient composition of important fish species in Bangladesh and potential contribution to recommended nutrient intakes. Journal of Food Composition and Analysis. 2015; 42: 120-133.

[9] Zenebe T, Ahlgren G, Gustafsson IB, Boberg M. Fatty acid and lipid content of Oreochromis niloticus L. in Ethiopian lakes: dietary effects of phytoplankton. Ecol Freshw Fish. 1998a; 7: 146-58.

[10] Zenebe T, Ahlgren G, Boberg M. Fatty acid content of some freshwater fish of commercial importance from tropical lakes in the Ethiopian Rift Valley. J Fish Biol. 1998b; 53: 987-1005.

[11] Zenebe T. Diet composition impacts the fatty acid contents of Nile tilapia, Oreochromis niloticus L. in Ethiopian highland lakes. Verh. Internat. Verein. Limnol. 2010; 30 (9): 13631368 .

[12] Emire SA, Gebremariam MM. Influence of frozen period on the proximate composition and microbiological quality of Nile tilapia fish (Oreochromis niloticus). Journal of Food Processing and Preservation. 2010; 34 (4): 743-757.

[13] Alemu LA, Melese AY, Gulelat DH. Effect of endogenous factors on proximate composition of Nile tilapia (Oreochromis niloticus L. fillet from Lake Zeway). Am J Res Commun. 2013; 1: 405-410. 
[14] Teame T, Natarajan P, Tesfay Z. Proximate and mineral composition of some commercially important fish species of Tekeze reservoir and lake Hashenge, Ethiopia. Int. J. Fish. Aquat. Stud. 2016; 4: 160-164.

[15] Tsegay T, Natarajan P, Zelealem T. Analysis of Diet and Biochemical Composition of Nile Tilapia (O. niloticus) from Tekeze Reservoir and Lake Hashenge, Ethiopia. J Fisheries Livest Prod. 2016; 4: 2.

[16] AOAC. Association of Official Analytical Chemists. Official Methods of Analysis. AOAC International, Gaithersburg, Maryland, U.S.A. 2005; 18.

[17] AOAC Association of Official Analytic Chemists. Official method of analysis. AOAC international, Washington, DC, U.S.A. 2000; 17 (II).

[18] Folch J, Lees M, Sloane-Stanley GH. A simple method for the isolation and purification of total lipids from animal tissues. J. Biol. Chem. 1957; 226: 497-509.

[19] AOAC Association of Official Analytic Chemists. Official method of analysis. AOAC international, Washington, DC, U.S.A. 1995.

[20] FAO/INFOODS. Food Composition Database for Biodiversity. Food and Agriculture Organization of the United Nations, Rome, Italy. 2013; 2.1. 